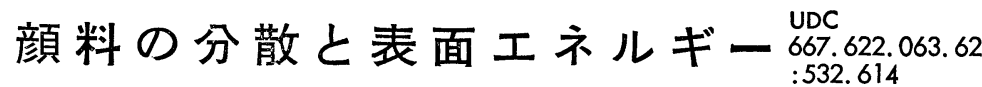

\section{Dispersibility of pigments and their surface energy}

\section{久 野洋* \\ KUNO Hirosi}

$$
W=\frac{t_{1 / 2}}{t_{1 / 2}^{0}}=2 a \int_{2 a}^{e} e^{\infty} V / k T \frac{d R}{R^{2}}
$$

の測定や，定性的な測定は数多く見られる。しかしなが ら，われわれにとって望ましいことは，顔料の物性と， 分散媒の物性とを知り, これらの組み合わせによって, この分散系の安定性を予測し得る事である。そのために 纱，顔料表面のエネルギー，または，自由エネルギー， および，これらによって生じる，顔料粒子間の相互作用 のポテンシャルを定量的に知り，これの分散媒の分子の 性質による变化を求めて, 定量的にその分散系の安定性 を求められればよい。現在の研究の段階は, このような 事を望むのにはいまだほど遠いといわねばならないが, そのために多くの努力がなされて物り, 以下これらの一 部を紹介し, 研究の端緒をつかむ一助ともなれば幸いで 女る。

\section{1. 粒子間の相互作用のポテンシャル}

顔料分散系の㠜集を速度論的飞考光れば，媒質中に招 いて顔料粒子が運動し，その粒子間の衝突の際に凝集が 起こるものと考兄られる。衝突したものがすべて凝集を 起こす，すなわち，衝突数がそのま凝集の速度となる 場合が，すみやかな凝集 rapid coagulation と呼ばれ， この時, 凝集により, 粒子数が, 最初の粒子数 $n_{0}$ の半 分になるに要する時間 $t_{1 / 2}^{0}$ は,

$$
\begin{aligned}
& t_{1 / 2}^{0}=\frac{1}{8 \pi D a n_{0}} \\
& D=k T / \pi \eta a
\end{aligned}
$$

となる1)。ただし， $a$ は粒子半径， $\eta$ は液の粘度， $T$ は 温度である。このような場合には, 粒径, 温度, 液の粘 度が，凝集速度を支配する大きな因子となっている。

多くの場合, 粒子間には, 相互作用のポテンシャルV 肪存在し, 上述の場合は, $\mathrm{V}=0$ の場合に相当する。こ のような相互作用のポテンシャルが存在するときに, 凝 集により粒子数が半減するに要する時間 $t_{1 / 2}$ と, 式 (1) の $t_{1 / 2}^{0}$ との比を安定比 Stability ratio $W$ と呼び, こ れは，

昭 39.8.3 受理

*慶応義塾大学工学部
であらわされる2)。ここで，Rは粒子の中心間距離であ る。粒子濃度, 粒径なぞによっても異なるが, 分散系の $t_{1 / 2}$ が約 1 ケ月程度になるよ5な安定性を示すためには， 上式によって，Vは 15〜25kT となればよい。

粒子間の相互作用のポテンシャルは, 粒子の有する, 主として電気的ポテンシャルに起因する瓜力のポテンシ ャル $V_{R}$ と, 主として Van der Waals 力に起因する 引力のポテンシャル $V_{A}$ との和，すなわち， $V=V_{A}+$ $V_{R}$ と考觉られている。

電気的ポテンシャルによる斥力への影響に関しては, Verwey \& Overbeek ${ }^{3)}$ らをはじめとして, 多くの研究 がなされて和りまた，この電気的ポテンシャル，すな わち， らポテンシャルの測定例も数多く発表されてい る。しかしながら, 引力のポテンシャルは, これを独立 に測定することも困難であり，また，理論的な解析もむ ずかしい。

分散系の凝集速度を測定し，これより式 (2)による粒 子間の相互作用のポテンシャルを求めることができる。 凝集速度を所定の系について測定し，次に，同様の系で， $V=0$ であるよらな場合について, す及やかな凝集速度 を測定すれば, これらの測定値より, 所定の系の $W$ の 值が求められ, これより相互作用のポテンシャルを式 （2）により算出することができる。このような方法によ り，Ottewill 和よび渡辺ら ${ }^{4)}$ は, 沃化銀ゾルにつき，W 々電気的ポテンシャルなどの関係を詳しく述べている。 このような凝集速度の測定は, 分散系の光透過度により 行なわれているが, この方法は, 濃厚な系や, 粒子が大 きく沈降の速い系には適用できず，また，これに代わる 適当な方法がないため, 一般にはこのような測定は相当 困難であって, 実際には速度論的な取り扱いが望ましい にもかかわらず，あまり多くの研究例が見られない。ま た, 相互作用のポテンシャルについては, 電気的ポテン

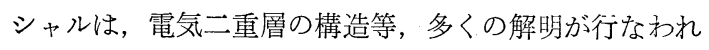
ているが, 非電気的なポテンシャルについては, Van der Waals 力によるポテンシャルとして述べられてお 
り， $V_{A}$ の形は粒子間の距離と, 粒子を形成する原子に より定まる定数との関数として求められているが, 後者 の定数の決定が理論的には困難でめり, 実験的手段に頼 らなければならないが，これもまた困難なのが現状であ る。

\section{2. 界面自由エネルギー}

前述のような, 速度論的な研究の困難のため, 分散系 の安定性の予測関して熱力学的な考光方が進められて いる。すなわち, 凝集の起こる前後に扔ける自由エネル ギーの変化を見れば，その変化の大小により，上り安定 な状態よりどれだけずれているかを判定する事ができる から，これょり凝集の起こる可能性の大小が予測され る。この扱い方は, 凝集現象乞のものよりも凝集と密接 な関係があると考光られる, 固体面の液体による奴れや すさについて適用されているが，いま，ぬれの形による 自由エネルギーの変化を示せば次の上うになる。

付着妨 Work of Adhesion

$$
W_{L / S}=\left(\gamma_{V / L}+\gamma_{V / S}\right)-\delta_{L / S}
$$

拡張机 Spreading Coefficient

$$
S_{L / S}=\gamma_{V / S}-\left(\gamma_{V / L}+\gamma_{L / S}\right)
$$

浸漬好 Adhesion Tension

$$
A_{L / S}=\gamma_{V / S}-\gamma_{L / S}
$$

ここで， $V / L, L / S$, 抢よび $V / S$ は，それ艺れ，気液， 固液、括よび固気界面をあらわし， $r$ は界面自由エネル ギーと数值的に等しい界面張力を示す。いずれの場合も， 右辺の第 1 項がぬれの起こる前の状態, 第 1 項より減じ られる第 2 項がぬれの後の状態に対応し，したがって， この二項の差, すなわち, すなわち, 式の左辺の值が正 で大である漂ど，ぬれの起こる可能性は大となる。それ ぞれのぬれの形に対して，その起こりやすさを示す自由 エネルギー変化に対し, 英語で示したような呼称がつけ られているが，分散の起こりやすさととくに関係が深い と思われるのは, 式(5)の Adhesion Tension である。 この量は, 粉体が, 気体中より液中に入り, 気固界面が 固液界面に変わる時の自由エネルギー変化の符号を変兄 たものである。液中の粉体の㠜集は, 固液界面が固体固 体間の界面ともいうべきものに変わる現象であって，そ の自由エネルギー変化は, Adhesion Tension と等しく はないが, その自由エネルギー变化は, 定義も測定も困 難であるため,これにもっとも近いと思われる Adhesion Tension を目安として用いることがある。

\section{3. 臨界表面張力}

固液界面に括ける, 界面張力の関係を測定するもっと

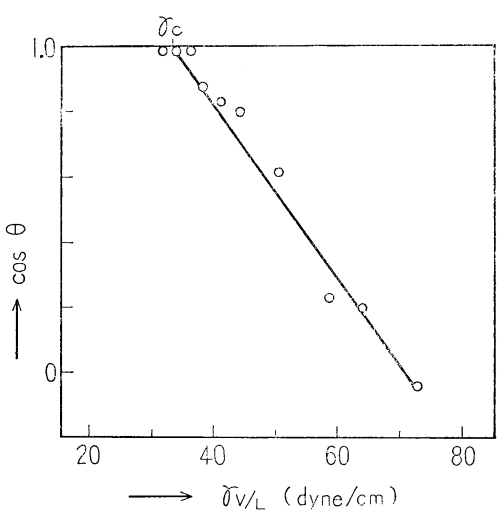

図-1 ポリエチレンの臨界表面張力

も通常の方法は接触角の測定である。Zisman ${ }^{5}$ は，低工 ネルギーの固体表面上飞拈いて, 表面張力 $\gamma_{V / L}$ の異な る有機の同族列の液体の接触角 $\theta$ を測定し，図-1 のよ うに，表面張力と $\cos \theta$ を両軸にとって測定点を示すと 直線となる結果を得, この直線と $\cos \theta=1$ の線が交わ る点の表面張力を臨界表面張力 $\gamma_{C}$ と名づけた。このよ うな直線関係は，かならずしも有機の同族列とは限らず。 濃度の異なる界面活性剂溶液などによっても得られるが, 高表面張力の側では直線から外れて彎曲することが多く， これは, 液固間に水素結合が生じたり, または, ミセル 形成なぞにより液の構成が変化するためであるとされて いる。

Zisman は， $\delta_{C}$ の值の大きい固体ほど，ぬれやすい固 体であり， $\gamma_{C}$ の值がぬれやすさの尺度となるとしてい る。彼は, 多くの固体面, 抢よび表面処理を施した固体 面について測定を行ない，これらを $\gamma_{C}$ の大きさの順に 並べた，ぬれやすさのスペクトル図を作成している。た とえば, ポリエチレンでは $\gamma_{C}$ は $31 \mathrm{dyne} / \mathrm{cm}$ であるが, この水素を塩素で置換するほど $\gamma_{C}$ は大となり，また， 水素をフッ素で置換するほど $\gamma_{C}$ は小となるなど, 固体 面の組成による妨やすさの変化を示している。このよ うな低エネルギー固体面では，その構成から考觉て，電 気的ポテンシャルの影響は小さく，したがって，このよ らなぬれやすさの差異は, 非電気的ポテンシャルによる ものである事は注目されてょい。

Young Dupré の式によれば,

$$
\gamma_{V / S}=\gamma_{L / S}+r_{V / L} \cos \theta
$$

これより

$$
\cos \theta=\frac{\gamma_{V / S}-\gamma_{L / S}}{\gamma_{V / L}}
$$

となる。いま，同族列の有機液体のよう飞性質の似た液 を用い, 固液間の結合の関係している， $\gamma_{L / S}$ の值が，液 
体によってほとんど変化しないものと考えられるならば， Zisman の方法により求めた, $\cos \theta=1$ の時の $\gamma_{V / L}$ の 值, すなわち, $\gamma_{C}$ は, $\gamma_{C}=\gamma_{V / S}-\gamma_{L / S}=A_{L / S}$ となる。 したがって, 同族列の液体を用いて, 各種の固体につい て $\gamma_{C}$ を求めて比較することは，これらの固体に関する Adhesion Tension $A_{L / S}$ ，または， $\gamma_{V / S}$ を比較したこ ととなり，队れやすさを比較していることとなる。低エ ネルギー固体面と飽和炭化水素液体との組久合わせに括 いては, $\gamma_{L / S}$ は, Van der Waals 力によって支配され， 固体による差異が小さく, 上記の仮定が成立する。しか し, 高エネルギー固体面に拈いては, 液体との間に, 水 素結合等の多くの形の結合が寄与し， $\gamma_{L / S}$ の固体によ る変化が大きく, 上記の仮定は成立せず, また, 図-1の ような网も，直線から外れ， $\gamma_{C}$ の意味も不明確となる。 このこそについては,さらに後述する。

\section{4. 湿 潤 熱}

接触角によるぬれやすさの測定は数多くなされている が，粉体に関しては，接触角そのものの測定が困難であ るため, もっと直接的にエネルギー変化を熱測定により とらえる試みがなされている。すなわち，気体中または 真空中に保持された粉体を, 液中に投入し, その時発生 する熱量を測定すれば，この值は，Adhesion Tension を求める時の過程に対応するエネルギー変化を求めた事 となる。この時測定される熱量を湿潤熱と呼ぶ。この湿 潤熱は, この過程のエンタルピー(熱含量)変化であって, このままでは, 自由エネルギー変化である Adhesion Tension とは一致しない。

この湿潤熱を $h_{E}$ とすれば,

$$
h_{E}=E_{W}+E_{\alpha}+E_{\mu}
$$

とあらわされる6)。ここで, $E_{\mu}$ は固体表面の電場と液体 分子の双極子能率との静電的相互作用の結合によるエネ ルギー変化， $E_{W}$ は，液体分子により誘起された固体面 の双極子と液体分子との相互作用, すなわち, Van der Waals 力，または London dispersion force による結 合のエネルギー変化， $E_{\alpha}$ は，液体分子の固体面への配 向によって生ずるエネルギー変化である。

固体拈よび夜体分子が，いずれも極性を有するときは, $E_{\mu}$ は, 固体面の電場の強さ $F$ と, 液体分子の双極子 能率 $\mu$ との積, $E_{\mu}=F \mu$ となる。ただし, これは吸着液 体分子 1 個についての值であって， $E_{\mu}$ を単位固体表面 積について考えるときは, 液体分子の吸着断面積による 換算が必要である。固体・液体のいずれか一方，または 双方が極性を有しないときには， $E_{\mu}=0$ となる。

$E_{W}+E_{\alpha}$ は, 前節の $\gamma_{L / S}$ について述べたと同様に,

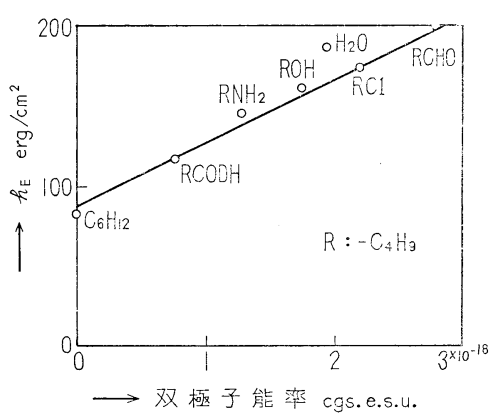

図-2 アナターゼの湿潤熱と液の双極子能率

表-1 固体面の電場の強さ $F$ 㧊よび $E_{W}$

\begin{tabular}{l|r|r|r}
\hline & $\begin{array}{c}\text { 比表面積 } \\
\mathrm{m}^{2} / \mathrm{g}\end{array}$ & $\begin{array}{c}F \\
\text { e.s. u. } / \mathrm{cm}^{2}\end{array}$ & $\begin{array}{r}E_{W} \\
\mathrm{ergs} / \mathrm{cm}^{2}\end{array}$ \\
\hline Rutile & 6.4 & $2.0 \times 10^{-5}$ & 125 \\
$\mathrm{SiO}_{2}$ (Aerosil) & 120 & 1.1 & 75 \\
$\mathrm{Al}_{2} \mathrm{O}_{3}$ & 0.4 & 1.9 & 335 \\
Graphon & 95 & 0 & 80 \\
Teflon & 9.0 & 0 & 25 \\
Iron blue & 87 & 2.2 & 105 \\
Chrome yellow & 6.7 & 1.9 & 105 \\
Carbon black & 120 & 0.7 & 105 \\
\hline
\end{tabular}

液体分子が似た性質のものであれば，液体分子が変わっ てもあまり変化せず, 液体の種類にかかわらず一定と仅 定できるとすれば，式（８)により，湿潤熱 $h_{E}$ は， $E_{\mu}$ の 值, すなわち, 使用する液体分子の双極子能率 $\mu$ と直線 的関係にある。ただし，このとき液体分の吸着断面積も 変わらないものと仮定する。図-2に示すように, n-ブチ ルの誘導体を用い, 液体分子の双極子能率に対し, 湿潤 熱を図示すれば直線関係が得られ，前述の関係を証して いる。この直線の傾斜より, 固体面に扣ける電場の強さ $F$ が算出され，多少とも極性を有する固体に関しては， 表-1 に示すように，Fの值により固体面の極性の大小 を比較することができる。

湿潤熱と液体分子の双極子能率との間に直線関係が得. られる事は, ひとつの固体に対しては, 液体の種類が異 なっても， $E_{W}+E_{a}$ の值が， ほぼ一定とみなし得ること を示しているが, 固体が変われば, 固体によって $E_{W}+$ $E_{\alpha}$ の值は変化する。 $E_{\alpha}$ の值は小で無視し得るとすれば 図-2 の直線が，双極子能率 0 の軸を切る点の $h_{E}$ の值に より $E_{W}$ が求められる。表-1 に示すように, $E_{W}$ の值 は, 固体の種類により大きな変動を示している。顔料の 非極性液体中に括汀る分散に関しては， $E_{\mu}$ の值よりも， この $E_{W}$ の值が意味を有しているものと考えられるが, この $E_{W}$ の意味に関する十分な研究はなされていない。 このように, 湿潤の測定により, 極性, 非極性の力に 
起因するエネルギー変化が求められるが，ここに求めら れるものは, エンタルピー変化であって, これと自由エ ネルギー変化とは次のような関係にある。

$$
h_{E}=\left(\gamma_{S}-\gamma_{L / S}\right)-T \frac{\partial\left(\gamma_{S}-\gamma_{L / S}\right)}{\partial T}
$$

ここで, $\gamma_{S}$ は真空中に和ける固体の表面自由エネルギ 一である。式(9)より分るように， $\gamma_{S}-\gamma_{L / S}$ より $h_{E} を$ 求めるためには, $\gamma_{S}-\gamma_{L / S}$ の温度変化を知る必要があ るが，これに関する十分な実験例は得られていない。ま た，式(9)に抹いて， $\gamma_{S}$ を用いるか， $\gamma_{V / S}$ を用いるか 関しては，蒸気中に持ける固体面への分子の吸着状態 の問題など, 多くの問題が残されている。

いま, 非常にあらい近似として, 式 (9)の右辺の第 2 項 $\partial\left(\gamma_{S}-\gamma_{L / S}\right) / \partial T$ が非常に小さく無視し得るものとす れば, $h_{E} \fallingdotseq \gamma_{S}-\gamma_{L / S}$ となり，また， $\gamma_{S}$ と $\gamma_{V / S}$ を等し いと和くものとすれば, 式 (6)を用いて

$$
h_{E} \fallingdotseq \gamma_{V / L} \cos \theta
$$

となる。筆者らは, ルチルおよびアナターゼに対して, クーブチル誘導体を用いた実験に和いて，浸透速度法によ り求めた。 $r r_{V / L} \cos \theta$ (ただし， $r$ は浸透の有効毛管半 径) と, 湿潤熱との間に比例関係を得, 式(10)を証する ような結果を得たが，現在のところ，これが偶然である 功, 特別な意味を有するものであるかを, 確認するに至 っていない。

\section{Dispersion force の界面張カえの寄与7)}

液体または固体の表面張力は, 表面に和ける原子また は分子が，内部の原子または分子とは異なり，一方の側 からのみ結合力を受けるためである。この表面同志が接 すると, 他の原子または分子により作用される結合力に より表面張力が変り両者の間に界面張力が生ずる。この 表面張力または界面張力の起因となる 結 合力は, Van dder Waals 力または London の dispersion force, 水 素結合力, 金属結合力执よび静電的引力等の寄与に分け て考える事ができる。Disperson force は他の結合力と 任とんど相互作用がなく独立に㗢くと仮定でさるので, 表面張力 $\gamma$ は, Dispersion force による寄与 $\gamma^{d}$ と, 他 の結合力による寄与 $\gamma^{2}$ との和としてあらわすことがで きる。すなわら, $r=r^{d}+r^{e}$, 炭化水素のような物質で は，ほとんど全部が Dispersion force による寄与であ るから, $\gamma=\gamma^{d}$ となり, 水銀では金属結合の寄与 $\gamma^{m}$ が 考㝋られ, $\gamma=\gamma^{d}+\gamma^{m}$ となる。

表面張力がそれぞれ $\gamma_{1}$ 抢よび $\gamma_{2}$ である 2 つの物質 泣接触して界面を形成するときには，これらの表面張力 々共に，その界面には，2つの物質の原子または分子間
の相互作用が働く。いま，一方の物質を，炭化水素の液 体のように, Dispierson force のみを有する物質とすれ ば，この相互作用は，2つの物質の Dispersion force のみの相互作用となり，その大きさは，それぞれの物質 の Dispersion force の寄与の幾何平均值 $\left(\gamma_{1}^{d} \gamma_{2}^{d}\right)^{1 / 2}$ 々 考劣るこができる。この相互作用の力の方向は, それ ぞれの物質の表面張力を生ぜしめるように働いている力 と逆方向であるから，これらの表面張力と，2つの物質 間の相互作用との結果として得られる界面能力 $\gamma_{12}$ は,

$$
r_{12}=\gamma_{1}+r_{2}-2 \sqrt{\gamma_{1}^{d} \gamma_{2}^{d}}
$$

となる。あるいは, 一方を固体, 他方を液体とすれば,

$$
r_{L / S}=\gamma_{V / S}+r_{V / L}-2 \sqrt{r_{V / S}^{d} \gamma_{V / L}^{d}}
$$

\section{とあらわされる。}

式(12)に, 式(16)の Young Dupré の式を代入すれば, $r_{V / L} \cos \theta=-\gamma_{V / L}+2 \sqrt{\gamma_{V / L}^{d} \gamma_{V / S}^{d}}$

となり,これより,

$$
\cos \theta=-1+2 \sqrt{\gamma_{V / S}^{d} \times \sqrt{ } \gamma_{V / L}^{d} / \gamma_{V / L}}
$$

となる。同様にして, 式(4)の Spreading Coefficient は, $\quad S_{L / S}=\gamma_{V / S}-\left(\gamma_{V / L}+\gamma_{L / S}\right)$

$$
=2 \sqrt{\gamma_{V / S}^{d} \gamma_{V / V}^{d}}-2 \gamma_{V / L}
$$

とあらわされる。

Zisman の測定した， $\gamma_{V / L}=\gamma_{V / L}^{d}$ とみなされる。飽和 炭化水素の液体の固体面上に拈訂る接触角と液体の表面 張力の結果を用いて, $\cos \theta$ と $\sqrt{\gamma_{V / L}^{d} / \gamma_{V / L}}$ (をたは, $\left.1 / \sqrt{\gamma_{V / L}}\right)$ を両軸にとり図示すれば, 図-3 のように, $\cos \theta=-1$ の点を通る直線が得られ, 式 (13)と一致する。 この直線の傾斜より $\gamma_{V / S}^{d}$ の值が得られ, これを図の $\cos \theta=1$ の線上に示した。この $\gamma_{V / S}^{d}$ の值は, Zisman の $\gamma_{C}$ の值と非常に近いが, 多少異なる值となる。

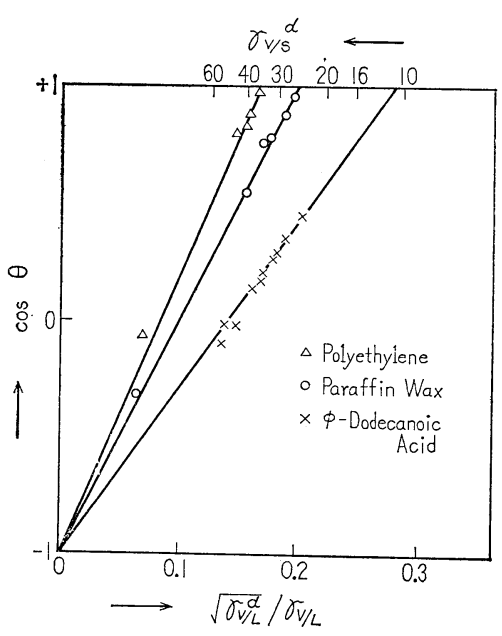

図-3 固体の接触角と $r_{V \text { s }}^{d}$ 
$\gamma_{V / L}^{d}$ の不明な液体と, $\gamma_{V / L}=\gamma_{V / L}^{d}$ と考えられる液体 との間の, 液液間の界面張力を測定し, 式(11)を用いれ ば， $\gamma_{V / L}^{d}$ の不明な液体の $\gamma_{V / L}^{d}$ を求める事ができる。 飽和炭化水素の液体と水との間の界面張力より, 水の $r_{\mathrm{H}_{2} \mathrm{O}}^{d}$ を水めれば, $\gamma_{\mathrm{H}_{2} \mathrm{O}}^{d}=21.8 \pm 0.7 \mathrm{dyne} / \mathrm{cm}\left(20^{\circ} \mathrm{C}\right)$ と なり, 水銀については, $\gamma_{\mathrm{Hg}}^{d}=200 \pm 7 \mathrm{dyne} / \mathrm{cm}\left(20^{\circ} \mathrm{C}\right)$ と なる。

図-3 より求められた，パラフィンの $\gamma_{V / S}^{d}=25 \mathrm{dyne} /$ $\mathrm{cm}$ と, $\gamma_{\mathrm{H}_{2} \mathrm{O}}^{d}=21.8 \mathrm{dyne} / \mathrm{cm}$ を, 式(13)に代入すれば, 接触角は $111^{\circ}$ となるが，測定值は $110 \pm 2^{\circ}$ となり，よ い一致を示し，このように液が極性を有していても，固 体が非極性であるときには, 式(13)が適用されることが 示される。しかしながら，界面を形成する 2 つの物質の 間に, 水素結合その他の結合力が作用するときには, 上 記の関係は適用できない。

\section{6. 結 び}

上記のように界面のエンタルピー，自由エネルギーな ぞの熱力学的量に関する研究が進められているが, これ らの熱力学量は, その本質からして絶対值は得られず, そのため, 気固表面または真空中の固体面と, 液中の固 液界面との間の熱力学量の変化がとられている。しかし ながら，この固体の真空中に拉ける界面をとるか，また は，蒸気中に括ける固体表面をとるかによって値は異な り, 蒸気中では, 蒸気圧の変化, したがって, 吸着量の 変化によっても值は異なってくるし, また, 分散一凝集 の過程で問題になるのは, 凝集した固体間の界面と液中 に分散した時の固液界面との間の熱力学量の变化である から, このような, 気固界面と固液界面との間の変化に より，分散のしやすさを比較することは適当とは言えな い。凝集状態に岁る粉体間の固体間界面が，ぞの液中に 掞いても同じであると仮定できるならば，分散に問題と なるのは固液界面に打ける熱力学量の大きさである。そ れゆえ, 液体または固体について系列的に分散のしやす さを比較するためには，ひとつの標準液体（たとえば, 特定の飽和炭化水素液体) を定め, この液体中に搞ける 固液界面と, 他の液体中に括子る固液界面との間の熱力 学量の差を以て分散の可能性の目安とすればよいと考兄 られる。
このような界面の熱力学量については, まだ, エンダ ルピーと自由エネルギーとの関係についても十分な測定: 例がない状態であるが, 分散の安定性を定量的に求める ためには，はじめに述べたように，液中に抽ける粒子間 の相互作用のポテンシャルが必要であって, このポテン シャルと熱力学量の関連などは今後の解決されるべき大 きな問題で岁る。

顔料の分散についてとくに強調したいのは, いわゆる Van der Waals 力の役割である。現在まで，らポテンシ ヤル等の電気的ポテンシャルの研究には相当見るべきも のがあるが，今後は，有機液体を扱う上にも重要であ， る。Dispersion force につきもっと注目されるべきであ. ると考学れる。また，本稿には書くことを避けたが， 液体が溶液である場合には, 液中の固体面に吸着層を生 じ, これについてのポテンシャル熱力学量の問題は,さ らに複雑性を加光, 今後の大きな問題となっている。

最後に, 本稿を書くにあたり,アメリカ化学会から発行 された F.M. Fewkes 編 “Contact Angle, Wettability and Adhesion" Advances Chemical Series No. 43: （1964）（文献 7）を参考にしたが，本書は，W. A. Zisman が Kendall 賞を受けたのを記念した Symposium であって, 界面張力などに関する有益な論文が多く, 興: 味ある万々の御一読を和すすめしたい。

\section{文献}

1) M. Smoluchowski, Physik. Z. 17, 557, 585, (1916) ; Z. physik. Chem. 92, 129 (1917)

2) N. Fuchs, Z. Physik. 89, 736 (1934)

3) E. J. W. Verwey and J. Th. G. Overbeek, "The-ory of the Stability of Lyophobic Colloids.", 1948 Elsevier Pub. Co.

4) 渡辺昌, 粉体拈よび粉末治金, 11，73 (1964)； R. H. Ottewill and A. Watanabe, Kolloid Z. 170, 38 (1960), 170, 132 (1960), 173, 7 (1961)

5) M. K. Bernett and W. A. Zisman, J. Phys. Chem. 63, 1241 (1959) ; E. G. Shafrin and W.A. Zisman, J. Phys. Chem. 64, 519 (1960)

6) F.H. Healey, A.C. Zettlemoyer and G. J. Young, J. Phys. Chem. 58, 887 (1954), A. C. Zettlemoyer, J. J. Chessick and C. M. Hollabaugh, ibid. 62, 489 (1958)

7) F. M. Fowkes, Advances in Chemistry Series; No.43, 99 (1964) 